九州大学学術情報リポジトリ

Kyushu University Institutional Repository

Taxonomic Studies on the Genus Tefenomus Haliday of Japan and Korea (Hymenoptera, Scelionidae) Part II

Ryu, Joon

Entomological Laboratory, Faculty of Agriculture, Kyushu University

Hirashima, Yoshihiro

Entomological Laboratory, Faculty of Agriculture, Kyushu University

https://doi.org/10.5109/23811

出版情報: 九州大学大学院農学研究院紀要. 30 (1)，pp.31-51，1985-09. Kyushu University バージョン：

権利関係: 


\title{
Taxonomic Studies on the Genus Tefenomus Haliday of Japan and Korea (Hymenoptera, Scelionidae) * Part II
}

\author{
Joon Ryu** and Yoshihiro Hirashima \\ Entomological Laboratory, Faculty of Agriculture, \\ Kyushu University, Fukuoka 812, Japan \\ (Received May 17, 1985)
}

\begin{abstract}
In this paper (Part II), descriptions of two new species, Telenomus sudoensis Ryu from Korea and T. kyushuensis Ryu from Japan, are presented. Two species, i. e., T. rowani (Gahan) and monodactylus Liu from Korea and 2 species, acrobates Giard and monodactylus Liu from Japan are recorded for the first time, respectively. A key to all the 25 species except $\mathbf{T}$. atamiensis Ashmead is given.
\end{abstract}

(16) Telenomus dendrolimi (Matsumura, 1925)

(Figs. 17, 37, 52, 58)

Gen. et sp. ? Niijima, 1903, Forest Protect., 1: 292.

Holcaeus sp. Takagi, 1925, Rep. Forest Exp. Stat. Chosen, No. 2: 35-36.

Holcaeus(?) dendrolimi Matsumura, 1925, Ann. Mus. 2001. Acad. Imp. Sci. 1'URSS.: 44. Female and male.

Holcaeus(?) dendrolimi: Matsumura, 1926, Jour. Agric. Hokkaido Imp. Univ., 18: 36. Female and male.

Phanurus sp.: Kanmiya, 1934, Rep. Forest Exp. Stat. Chosen, No. 18: 52.

Telenomus dendrolimusi Chu. 1937. Ent. Phytopath., 5: 60. Female and male.

Telenomus dendrolimi: Ishii, 1937, Kontyû, 12: 104.

Telenomus dendrolimi: Kanmiya, 1939, Jour. Tokyo Agric. Univ., 6: 6.

Telenomus dendrolimi: Nobuchi, 1961, Forest Protect. News, 10: 180.

This species is similar to strelzovi, but differs from the latter in having the vertex and frons more broad, convex, interocular distance rather broad, antennae and legs entirely black, thorax raised above the level of metasoma, and metasoma rather short, broadest much beyond the middle and abruptly narrowed toward the apex.

Female: Black. Antennae black throughout. Legs entirely blackish except for trochanters, tips of femora and tibiae, and tarsi which are brownish yellow. Ovipositor light yellow.

Head transverse as seen from above, a little more than twice as broad as its median length and slightly broader than thorax (21:18); postero-lateral

* Contribution from the Entomological Laboratory, Faculty of Agriculture, Kyushu University, Fukuoka (Ser. 3, No. 174).

** Present address: Korea Atomic Energy Research Institute, P. 0. Box 7, Cheong Ryang, Seoul, Korea. 
portions behind eyes more or less well developed. Vertex broad with fine reticulate rugae and short hairs; posterior portion slanting into occiput, with a nearly complete preoccipital carina situated below the top of vertex; occiput broadly concave, minutely reticulate. Frons well convex, almost smooth and shining; subocular space punctate-sculptured near eye. Eyes with almost imperceptible short hairs. Posterior ocelli very close to inner orbit. Interocular distance rather broad, about 0.6 times as long as width of head as seen in front. Antennae 11-segmented; scape 5.2 times as long as broad, almost equal to pedicel and three funicle segments combined ; pedicel about 2.7 times as long as broad, 1.3 times as long as first funicle segment; first about 2.9 times as long as broad, 1.4 times as long as second; second slightly longer than broad; third quadrate, a little broader than long; fourth transversely rounded ; club distinctly 5 -segmented, proximal four segments slightly transverse and apical segment conical-ovate.

Thorax raised high above the level of metasoma; mesoscutum well convex anteriorly, but rather flat medially, closely reticulate and hairy;' scutellum smooth and shining with scattered punctures and covered with short hairs; postscutellum transverse, distinctly sculptured. Fore wings rather broad, 2.6 times as long as broad; stigmalis 0.4 times as long as postmarginalis and submarginalis slightly longer than postmarginalis. Hind wings 5 times as long as broad, distinctly broadened beyond nervature; fringes slightly shorter than $1 / 2$ of the greatest width of hind wing.

Metasoma rather short, a little longer than thorax, obviously longer than broad (25:18) and broadest beyond the middle ; first tergum longitudinally costate basally; second tergum a little shorter than broad (16:18), longitudinally striated in the middle basally; following terga abruptly narrowed toward apex. Ovipositor projecting a little beyond the tip of metasoma.

Male: Resembling female, but differs in the following characters.

Antennae 12-segmented; scape 4.7 times as long as broad; pedicel 1.8 times as long as broad, slightly shorter than first flagellar segment (15:19); second 2.5 times as long as broad, 1.2 times as long as third; third about 1.8 times as long as broad, 1.5 times as long as fourth; fourth to ninth distinctly shorter than first to third segments; each flagellar segment longer than broad. Apex of metasoma not so sharply narrowed as in female.

Length : 0.9-1. $0 \mathrm{~mm}$.

Host: Dendrolimus spectabilis Butler, D. albolineatus Mat., D. punctatus Walker (in Japan), Dendrolimus spectabilis B. (in Korea and China).

Distribution : Japan (Kyushu, Honshu, Hokkaido), Korea, China, Saghalien.

Specimens examined: 10 males, 21 females, Seoul, Korea, viii. 1978 (J. H. Ko) bred from eggs of D. spectabilis; 1 female, Mt. Baikbongsan, Kyunggi-do, Korea, 22. vii. 1982 (J. Ryu).

(17) Telenomus rowani (Gahan, 1925)

(Fig. 31)

Phanurus rowani Gahan, 1925, Philip. Jour. Sci., 27: 106. Female and male.

Phanurus rowani: Ishii, 1930, Oyo-Dobutsugaku-Zasshi, 2: 148.

Phanurus tainaneusus (sic) Ishida (n. n.), 1931, Rep. Jap. Assoc. Adv. Sci., 6: 539, 543. 
Telenomus rowani: Nixon, 1937, Ann. Mag. Nat. Hist., (10) 20: 460.

Phanurus rowani: Ishii, 1939, Oyo-Dobutsugaku-Zasshi, $11(3,4): 107$.

Telenomus rowani: Sonan (partim), 1943, Taiwan-Nojiho, 39: 377.

Telenomus row ani : Yasumatsu, 1950, Mushi, 21: 56.

Telenomus rowani: Masner, 1965, Bull. British Mus. Ent. Suppl., 1: 121.

This species is similar to dignus and appears to differ from it in having the head considerably more transverse, metasoma slender, distinctly concave, first tergum virtually unsculptured, and hind wing distinctly narrow and slender.

This species was originally described by Gahan (1925) from the Philippines (Luzon) based on a series containing both sexes bred from the eggs of the rice-borer, Schoenobiusincertellus Wlk.

Female: Black. Antennae and legs brownish black.

Head transverse as seen from above, about 2.3 times as broad as its median length and barely broader than thorax (11: 10). Vertex roundly convex into occiput, very finely reticulate-sculptured with sparse, short hairs; occiput concave; preoccipital carina not sharply defined and situated below the top of vertex. Frons rather flat, smooth and shining; subocular space sparsely punctate-rugose near eye. Eyes with extremely short hairs, not attaining posterior margin of head above and 1.5 times as long as broad; interocular distance about 0.6 times as long as width of head as seen in front. Posterior ocellar distance about 1.8 times as long as lateral ocellar distance. Antennae slender, 11-segmented; scape 4.9 times as long as broad; pedicel about twice as long as broad, 1.7 times as long as first funicle segment; first 1.6 times as long as broad; second and third subequal, subquadrate; fourth shorter than other segments; club 4-segmented, each segment a little longer than broad and apical segment conical-ovate.

Thorax a little longer than broad (10:9) ; mesoscutum rather flat, very weakly sculptured, shining and covered with very short hairs; scutellum polished and transverse. Fore wings rather narrow, about 3.7 times as long as broad; stigmalis rather short, about 0.3 times as long as postmarginalis and submarginalis slightly longer than postmarginalis. Hind wings distinctly narrow, about 8.9 times as long as broad; fringers a little longer than the greatest width of hind wing.

Metasoma lanceolate, distinctly concave, 2.5 times as long as broad and 0.8 times as broad as thorax; first tergum transverse, virtually unsculptured; second tergum striated at extreme base and longer than following terga combined.

Length : $0.8 \mathrm{~m} \mathrm{~m}$.

Host: Schoenobius incertellus Walker (in Japan, Formosa, China, Indo-China, India, Siam). Schoenobius incertellus Wlk., Scirpophaga innotata Wlk. (in Philippines, Java).

Distribution : Japan (Kyushu), Korea, Formosa, China, Indo-China, Siam, Philippines, Java. This is the first record of this species from Korea.

Specimens examined: JAPAN: 4 females, Mt. Tachibana, Fukuoka Pref., Kyushu, 15. vi. 1969 (0. Yata) ; 7 females, Mt. Inunaki, Fukuoka Pref., Kyushu, 24. vi. 1969 (0. Yata) ; 1 female, Ushine, Kagoshima Pref., Kyushu, 19. vii. 
1969 (0. Yata) ; 3 females, Kamiozoegawa, Fuji, Saga Pref., Kyushu, 13. iv. 1973 (K. Yamagishi) ; 1 female, Kamiozoegawa, Fuji, Saga Pref., Kyushu, 25. ix. 1973 (K. Yamagishi). KOREA: 2 females, Mt. Sudo (400 m), Kyungsangpukdo, Korea, 17-18. vii. 1971 (K. Yamagishi) ; 1 female, Mt. Sudo (700 m), Kyungsangpuk-do, Korea, 9-12. vii. 1971 (K. Yamagishi).

\section{(18) Telenomus acrobates Giard}

(Figs. 21, 25, 45)

Telenomus acrobates Giard, 1895, Bull. Soc. Ent. France: 67. Female and male.

Telenomus acrobates: Dalla Torre, 1898, Catal. Hym., 5: 513.

Telenomus acrobates: Kieffer, in André, 1912, Spec. Hym. Eur., 11: 25. Female and male.

Phanurus acrobates: Kieffer, 1926, Das Tierreich, 48: 52. Female and male.

Telenomus acrobates: Principi, 1947, Boll. 1st. Ent. Bolgana, 16: 148.

Telenomus acrobates: Kozlov, 1967, Ent. Obozr., 46: 370. Female and male.

The females of this species is somewhat similar to rowani, but is larger, the head just behind upper portions of eyes very narrow, not sharply carinate, antennae and legs darker, thorax distinctly convex as seen from side, metasoma not concave, second tergum not longitudinally striated and apical segments of metasoma slightly crooked downward.

Three females of this species were bred from the eggs of Chrysopa sp., a Neuropteron inhabiting Honshu and Shikoku, by T. Ishihara and K. Ito.

Female: Black. Antennae and legs dark brown to black except for basal segments of tarsi which are digny yellowish brown. Wings hyaline, veins brownish and mandibles reddish brown.

Head transverse as seen from above, about 2.7 times as broad as its median length and a little broader than thorax. Vertex convex into occiput, densely, minutely reticulate-sculptured and covered with sparse, short hairs; occiput somewhat concave. Frons broad, somewhat flat, in greater part smooth and shining with some feeble punctures near eye. Eyes with very short hairs, 1.3 times as long as broad; interocular distance to the width of head as seen in front, as $8: 15$. Posterior ocellar distance 1.4 times as long as lateral ocellar distance. Antennae rather slender, 11-segmented; scape 5.4 times as long as broad, slightly shorter than pedicel and three funicle segments combined; pedicel twice as long as broad, 1.3 times as long as first funicle segment; first about 1.6 times as long as broad, 1.3 times as long as second; second 1.3 times as long as broad, 1.3 times as long as third; third quadrate, a little longer than fourth; fourth rounded, slightly transverse; club 4-segmented, proximal first segment quadrate, second and third slightly transverse and apical segment conical-ovate, 1.5 times as long as broad.

Thorax, as seen from side, distinctly convex and slightly broader than metasoma ( $7: 6)$; mesoscutum finely reticulate-sculptured covered with short, pale hairs; scutellum somewhat bulging above, smooth and shining with some sparse punctures ; postscutellum strongly sculptured ; propodeum broadly and deeply excavated, only the lateral angles visible from above, these rather large and triangular. Fore wings about 2.9 times as long as broad; marginalis about $1 / 2$ as long as stigmalis, postmarginalis about 2.4 times as long as stigmalis and submarginalis 1.3 times as long as postmarginalis. Hind wings 
slender, 6 times as long as broad; fringes about $2 / 3$ of the greatest width of hind wing.

Metasoma about as long as thorax, slightly longer than broad; first tergum strongly transverse, longitudinally costate; second about as long as broad, carinate at only extreme base; following terga slightly crooked below.

Male: Antennae 12-segmented; scape about 4.3 times as long as broad, a little shorter than following three segments combined; pedicel 1.3 times as long as broad, a little shorter than first flagellar segment; first 1.3 times as long as broad, 0.8 times as long as second; second twice as long as broad, 1.2 times as long as third; third 1.6 times as long as broad, a little longer than fourth; fourth to ninth slightly longer than broad; apical segment pointed, 2.7 times as long as broad. Apex of metasoma not crooked downward. Otherwise like female.

Length : $0.7-0.8 \mathrm{~mm}$.

Host: Chrysopa sp. (in Japan and France),

Chrysopa perla L. (in USSR and Germany),

Chrysopa formosa Brauer (in Italy).

Distribution : Japan (Kyushu, Shikoku, Honshu), USSR, Germany, Italy. This is the first record of this species from Japan.

Specimens examined: 1 female, Tarumi, Matsuyama, Shikoku, 29. v. 1973 (T. Ishihara) bred from eggs of Chrysopa sp.; 2 females, Sakuradai, Nerima, Tokyo, Honshu, 5. x. 1974 (K. Ito) bred from eggs of Chrysopa sp.; 1 male, 1 female, Kamiozoegawa, Fuji, Saga Pref., Kyushu, 9. x. 1973 (K. Yamagishi); 2 females, Kamiozoegawa, Fuji, Saga Pref., Kyushu, 25. ix. 1973 (K. Yamagishi) ; 2 females, Kamiozoegawa, Fuji, Saga Pref., Kyushu, 10. viii. 1973 (K. Yamagishi) ; 1 female, Kamiozoegawa, Fuji, Saga Pref., Kyushu, 28. iv. 1973 (K. Yamagishi) ; 1 female, Kamiozoegawa, Fuji, Saga Pref., Kyushu, 13. iv. 1973 (K. Yamagishi) ; 1 male, Kamiozoegawa, Fuji, Saga Pref., Kyushu, 4. vii. 1973 (K. Yamagishi).

(19) Telenomus dignus (Gahan, 1925)

(Figs. 30, 49)

Telenomus sp. Nakagawa, 1900, Spec. Rep. Agric. Exp. Stat., 6: 15.

Phanurus beneficiens: Shiraki (nec Zehntner), 1917, Spec. Rep. Agric. Exp. Stat.. Gov. Formosa: 256.

Phanurus dignus Gahan, 1925, Philip. Jour. Sci., 27: 108. Female and male.

Phanurus dignus: Ishii, 1930, Oyo-Dobutsugaku-Zasshi, 2 : 148.

Phanurus matsumurai Ishida, 1931, Rep. Jap. Assoc. Adv. Sci., 6: 543.

Phanurus benejiciens: Okada, Maki et Kuroda (nec Zehntner), 1934, Nojikairyoshiryo, 69: 4.

Phanurus benejiciens: Okada et Maki (Nec Zehntner), 1934, Nojikairyoshiryo, 69: 2.

Telenomus dignus: Nixon, 1937, Ann. Mag. Nat. Hist., (10) 20: 462.

Phanurus dignus: Ishii, 1939, Oyo-Dobutsugaku-Zasshi, 11: 107.

Phanurus beneficiens: Takeno et Yanagihara (nec Zehntner), 1939, Injur. Benef. Ins. Sugarcane in Formosa: 149, 150. 255.

Telenomus dignus: Sonan, 1943, Taiwan-Nojiho, $39: 378$.

Telenomus dignus: Yasumatsu, 1950, Mushi, 21 (7): 57.

Telenomus dignus: Masner, 1965, Bull. British Mus. Ent., Suppl. 1: 113. 
This species is similar to acrobates, but differs from the latter in having the head, as seen from above, thick and rather rounded, interocellar distance rather narrow, vertex well convex, distinctly reticulate, posterior portion of mesoscutum rather flat, thorax not distinctly convex as seen from side, metasoma not small, more or less long and broad and fore coxae smoewhat darker.

Female: Black. Antennae dark brown, with only basal half of scape pale. Legs yellowish except for fore coxae. Wings hyaline, veins yellowish brown.

Head, as seen from above, thick and rather rounded, about 1.9 times as broad as its median length and a little broader than thorax (11 : 10). Vertex well convex and distinctly reticulate-sculptured with sparse, very short hairs and evenly rounded from anterior ocellus to occiput; interocellar space also reticulate-sculptured. Frons well convex, smooth but with sparse, shallow punctures; subocular space weakly punctate-sculptured near eye. Eyes with extremely short hairs, 1.2 times as long as broad; interocular distance to the width of head as seen in front, as $7: 15$. Posterior ocellar distance 1.7 times as long as lateral ocellar distance. Antennae ll-segmented ; scape 5.1 times as long as broad, almost equal to following four segments combined; pedicel about 2.3 times as long as broad, 1.5 times as long as first funicle segment; first 1.7 times as long as broad, slightly longer than second; second and third slightly longer than broad; fourth and fifth slightly transverse, fourth smaller than fifth; club C-segmented, proximal three segments subquadrate and subequal, and apical segment conical-ovate.

Thorax not distinctly convex as seen from side and barely longer than broad; posterior portion of mesoscutum rather flat, feebly shining and weakly reticulate, covered with pale hairs; scutellum slightly convex, polished with sparse, short hairs; metanotum and propodeum distinctly sculptured. Fore wings about 3.4 times as long as broad; postmarginalis about 2.6 times as long as stigmalis, submarginalis about 1.4 times as long as postmarginalis and stigmalis 1.8 times as long as marginalis. Hind wings about 5.8 times as long as broad; fringes about $2 / 3$ of the greatest width of hind wing.

Metasoma not small, more or less long and broad, about 2.1 times as long as broad; first tergum transverse with sharply defined longitudinal costae; second tergum about 1.2 times as long as broad, longitudinally striated at base and elsewhere smooth and shining; following terga strongly transverse with sparse, pale hairs.

Male: Black. Antennae yellowish brown except for apical four segments somewhat darker. Legs yellowish except fore coxae.

Antennae 12-segmented; scape slender, about 4 times as long as broad; pedicel 1.5 times as long as broad, hardly longer than first flagellar segment; first to third slightly longer than following segments; fourth to ninth more or less spherical. Metasoma not longer than thorax and a little narrower than thorax; subovate and its apex not truncate. Otherwise like female.

Length : 0.7-0. $8 \mathrm{~mm}$.

Host: Chilo simplex, Schoenobius incertellus Walker (in Japan), Schoenobius incertellus Wlk., Scirpophaga innotata Wlk. (in Philippines, Java, China), Schoenobius 
incertellus WIk., Chilo simplex, Chilo infuscatellus (in Formosa).

Distribution : Japan (Kyushu, Honshu, Shikoku), Korea, Formosa, Philippines, Java, China.

Specimens examined: 1 female, 1 male, Inunaki, Fukuoka Pref., Kyushu, 24. vi. 1969 (0. Yata) ; 1 female, Satamisaki, Tajiri, Kagoshima Pref., Kyushu, 17. vii. 1969 (0. Yata) ; 1 female, K. A. E. R. I., Seoul, Korea, 5. vii. 1982 (J. Ryu).

\section{(II) Group B: Antennae of female lo-segmented}

(20) Telenomus sudoensis Ryu, sp. n.

(Figs. 18, 42, 60)

Among the species of Telenomus having lo-segmented antennae in these areas, this species differs from others in having the antennal club distinctly 5-segmented, first funicle segment distinctly longer than pedicel and other flagella, face above antennal toruli finely strigate, second metasomal tergum longer than broad and body rather long.

Female: Black. Antennae black except for radicle which is brown. Legs yellowish brown except for coxae black and femora slightly infuscated. Wings hyaline, veins dark brown. Ovipositor dark brown.

Head transverse as seen from above, about 2.8 times as broad as its median length and slightly broader than thorax (11 : 9). Vertex and occiput reticulate-sculptured throughout and preoccipital carina somewhat dull. Frons smooth and shining; face above antennal toruli finely strigate; subocular space reticulate-sculptured near eye ; the space between eye and mandible long; upper portion of genal area distinctly carinate along eye margin. Eyes rather short, with dense short hairs and 1.2 times as long as broad; interocular distance a little longer than length of eye in frontal view (9:8). Posterior ocelli very close to inner orbit; posterior ocellar distance 1.8 times as long as lateral ocellar distance. Antennae lo-segmented ; radicle about 2.3 time as long as broad, about $1 / 5$ as long as scape; scape rather elongate, 6.1 times as long as broad, 3 times as long as pedicel; pedicel 2.5 times as long as broad, shorter than first funcle segment ( $7: 9)$; first distinctly longer than other flagella, 3.1 times as long as broad and 1.9 times as long as second; second slightly longer than broad $(5: 3)$, a little longer than third; third as long as broad; club 5-segmented, proximal first segment a little longer than broad, second to fourth transverse and apical segment conical-ovate.

Thorax slightly longer than broad (5:4), hardly broader than metasoma; mesoscutum reticulate-sculptured throughout with short hairs; scutellum rather large, semicircular, entirely smooth and shining with some punctures laterally; postscutellum finely reticulate-sculptured; propodeum roughly sculptured and only lateral angles visible as seen from above. Fore wings rather broad, 2.6 times as long as broad; stigmalis rather long, about 0.6 times as long as postmarginalis and submarginalis longer than postmarginalis (11: 8). Hind wings 4.8 times as long as broad; fringes about $1 / 3$ of the greatest width of hind wing. 
Metasoma 1.6 times as long as broad, nearly equal to head and thorax combined ; first tergum distinctly costate all over ; second tergum a little longer than broad (11:10) with longitudinal striae on basal $1 / 3$; third to seventh terga strongly transverse, punctulate throughout; ovipositor slightly projecting at the tip of meatasoma.

Length : $1.3 \mathrm{~mm}$.

Male and host: Unknown.

Distribution : Korea.

Type material: Holotype: female (Type No. 2218, Kyushu Univ.), Mt. Sudo (1,000 m), Kyungsangpuk-do, Korea, 13-14. vii. 1971 (K. Yamagishi). Paratypes : 2 females, Mt. Sudo (1,000 m), Kyungsangpuk-do, Korea, 13-14. vii. 1971 (K. Yamagishi).

\section{(21) Telenomus monodactylus Liu}

(Fig. 41)

Telenomus (Aholcus) monodactylus Liu, 1959, Acta Soc. ent. Csl. 56: 159. Female and male.

This species is similar to euproctidis, but is smaller, metasoma broadly concave, mesoscutum well convex anteriorly in outline, vertex and frons well convex, interocular distance rather broad and the space between eye and mandible short.

Female: Black. Antennae dark brown except for base of scape and radicle which are dusky yellow. Legs fuscous except for trochanters, basal four segments of tarsi, tibiae at base and apex which are yellowish brown. Wings hyaline and venation brownish.

Head transverse as seen from above, about 3.2 time as broad as its median length and slightly broader than thorax (11:9). Vertex well convex, reticulate-sculptured; upper portion of genal area and just behind eyes linear, not carinate but. sharp. Frons well convex, smooth and shining in the middle, some punctures along the inner orbit; subocular space microscopically punctate-rugose near eye; the space between eye and mandible short. Eyes large with very short hairs, about 1.3 times as long as broad; interocular distance to the width of head as seen in front, as $5: 8$. Posterior ocellar distance about 1.5 times as long as lateral ocellar distance. Antennae 10segmented, with club 4-segmented; scape elongate, almost equal to pedicel and three funicle segments combined; pedicel 2.1 times as long as broad, 1.2 times as long as first funicle segment; first twice as long as broad, about 1.4 times as long as second; second a little longer than broad; third subglobular and fourth distinctly smaller than next segment; proximal three segments of club transverse and apical segment conical, 1.7 times as long as broad.

Thorax more or less short, broadest at the level of tegulae, distinctly narrowed posteriorly and a little longer than broad (11:10); mesoscutum distinctly convex, closely, finely reticulate-sculptured and densely covered with minute hairs; scutellum smooth and shining with a few punctures; postscutellum transverse. Fore wings about 2.9 times as long as broad; stigmalis a little shorter than $1 / 2$ as long as postmarginalis and submarginalis slightly longer 
than postmarginalis (10:9). Hind wings about 6.6 times as long as broad; fringes about $2 / 3$ of the greatest width of hind wing.

Metasoma slightly longer than thorax $(9: 8)$, about 1.4 times as long as broad; first tergum transverse, longitudinally costate at base; second tergum a little shorter than broad, with longitudinal basal striae; following terga distinctly transverse, smooth and shining; ovipositor slightly projected at the tip of metasoma, about $1 / 5$ of the metasoma.

Length : 0.65-0. $7 \mathrm{~mm}$.

Host: Pygaerarufa Luh. (in China).

Distritution: Japan (Kyushu), Korea, China. This is the first record of this species from Japan and Korea.

Specimens examined: JAPAN: 4 females, Kamiozoegawa, Fuji, Saga Pref., Kyushu, 4. vii. 1973 (K. Yamagishi). KOREA: 2 females, Mt. Sudo (1,000 m), Kyungsangpuk-do, Korea, 13-14. vii. 1971 (K. Yamagishi) ; 1 female, Mt. Sudo (700 m), Kyungsangpuk-do, Korea, 9-12. vii. 1971 (K. Yamagishi) ; 2 females, Mt. Baikbongsan, Kyunggi-do, Korea, 19. ix. 1982 (J. Ryu).

\section{(22) Telenomus euproctidis Wilcox}

(Figs. 39, 53)

Telenomus euproctidis Wilcox, 1920, Psyche, 27: 79. Female and male.

Telenomus euproctidis: Minamikawa, 1956, Study of Tea, 15: 38.

This species is similar to kuboi, but differs from the latter in having the vertex transversely well ridged, frontal region not well convex and distinctly slanting. This is further characterized by the head considerably broader than thorax and postmaginalis almost equal to submarginalis.

This species was originally described from Japan by Wilcox (1920) based on several specimens reared from the eggs of Euproctisconspersa.

Female: Black. Antennae dark brown to black. Legs entirely brownish except for all coxae which are decidedly darkened; femora dark brown, tibiae paler than femora and tarsi yellowish brown. Wings hyaline, venation brownish.

Head transverse as seen from above, about 3 times as broad as its median length and distinctly broader than thorax (9: 7). Vertex transversely well ridged, frontal region not well convex and distinctly slanting with fine reticulate-sculpture. Frons finely reticulate, but in front of mid ocellus smooth and shining; subocular space with some punctures near eye. Eyes pilose, 1.3 times as long as broad; interocular distance to the width of head as seen in front, as $7: 11$. Posterior ocelli very close to inner orbit, mid ocellus in a shallow fovea; posterior ocellar distance 1.8 times as long as lateral ocellar distance. Antennae lo-segmented, with 4-segmented club; scape about 5.1 times as long as broad, 2.7 times as long as pedicel; pedicel 2.4 times as long as broad, 1.4 time as long as first funicle segment; first 1.6 times as long as broad, 1.7 times as long as second; second slightly transverse ; third and fourth distinctly transverse; proximal first segment of club quadrate, second and third transverse and apical segment conically pointed. 
Thorax a little longer than broad (11:10); mesoscutum convex anteriorly, reticulate-sculptured throughout and covered with silvery pale hairs; scultellum smooth and shining with scattered fine punctures; postscutellum finely sculptured. Fore wings about 2.7 times as long as broad; stigmalis about $1 / 2$ as long as postmarginalis; submarginalis nearly as long as postmarginalis. Hind wings 5.3 times as long as broad, distinctly broadened beyond nervature; fringes a little longer than $1 / 2$ of the greatest width of hind wing.

Metasoma longer than thorax (11:9), 1.6 times as long as broad ; first tergum transverse, nearly smooth and shining except for the extreme base which is longitudinally carinate; second tergum about 1.3 times as long as broad, striated at base; following terga short and coming to a point.

Male: Differs from female as follows: Antennae brown except for scape which is yellowish brown. Legs considerably paler than in female except for coxae. Metasoma not pointed at apex.

Antennae Q-segmented; scape 4.2 times as long as broad, almost equal to following four segments combined; pedicel 1.6 times as long as broad, 1.5 times as long as first flagellar segment; first 1.3 times as long as broad, as long as second; second as long as broad, 0.9 times as long as third; fourth to ninth shorter than first to third; apical segment pointed apically, about 1.5 times as long as broad.

Lengh : 0.75-0. $8 \mathrm{~mm}$.

Host: Euproctis conspersa Butl., E. flava Bremer, E. pseudoconspersa Strand, $E$. similis xanthocampa Dayr, E. similis Fuessly.

Distribution : Japan (Honshu).

Specimens examined: 12 males, 45 females, Matsugasaki, Kyoto, 3. vii. 1979 (K. Yamagishi) bred from eggs of Euproctis similis Fuessly.

\section{(23) Telenomus kuboi Yasumatsu}

(Fig. 38)

Telenomus (Aholcus) kuboi Yasumatsu, 1962, Kontyû, 30: 260. Female.

This species is closely related to euproctidis, but differs from it in having the frontal region of vertex and frons well convex with fine reticulation and posterior portions of eyes rounded, but with a carina along upper-hind margins of eyes.

The type specimen is well preserved in the Collection of the Entomological Laboratory, Kyushu University.

Female: Black. Antennae brownish or darkened; base of scape pale brownish. Legs obscure yellow except for apex of tarsi darkened.

Head transverse as seen from above, about 2.7 times as broad as its median length and distinctly broader than thorax $(9: 7)$. Vertex and occiput finely reticulate uniformly; posterior portions of eyes rounded, but with a carina along upper-hind margin of eye as seen from above. Frons finely reticulate-sculptured, the space just in front of mid ocellus shining. Eyes with sparse, short hairs, 1.2 times as long as broad; interocular distance to the width of head as seen in front, as $7: 13$. Posterior ocellar distance 1.3 
times as long as lateral ocellar distance. Antennae lo-segmented ; radicle rather short, about $1 / 5$ as long as scape; scape more than 3 times as long as broad, almost equal to following four segments combined; pedicel more than twice as long as broad, 1.5 times as long as first funicle segment; first 1.5 times as long as second ; second as long as broad; third a little transverse and fourth distinctly transverse ; club 4-segmented, proximal three segments slightly transverse and apical segment conical-ovate.

Thorax slightly longer than broad (10:9); mesoscutum finely reticulatesculptured, covered with short hairs; scutellum smooth and shining with sparse, short hairs; metanotum transverse, rugose and swollen. Fore wings 3 times as long as broad; postmarginalis indistinct, but more than twice as long as stigmalis and submarginalis 1.6 time as long as postmarginalis. Hind wings narrow, slightly but distinctly broadened beyond nervature, 5.7 times as long as broad; fringes about $2 / 3$ of the greatest width of hind wing.

Metasoma distinctly longer than broad (10:7), as broad as thorax; first tergum strongly transverse, closely longitudinally costate all over ; second tergum nearly as long as broad, with fine striae on basal fifth; following terga distinctly transverse, smooth and shining.

Length : Approx. $0.9 \mathrm{~mm}$.

Host: Polyura eudamippus weismanni Fritze.

Distribution: Japan (the Ryukyus).

Specimens examined: 10 females, Nago-machi, Okinawa, the Ryukyus, viii. 1962 (K. Kubo) bred from eggs of Polyura eudamippus w eismanni.

(24) Telenomus kyushuensis Ryu, sp. n.

(Figs. 19, 40, 59)

This species is very similar to kuboi, but differs from the latter in having the vertex strongly reticulate-sculptured, frons more broadly and more distinctly reticulate, mesoscutum more roundly convex, the distance between eye and mandible longer in lateral view, metasoma slightly narrower than thorax and first tergum less extensively longitudinally carinate.

Female: Antennae entirely dark brown to black throughout. Legs virtually black except for junctions of tibiae and basal segments of tarsi which are yellowish brown.

Head transverse as seen from above, about 2.6 times as broad as its median length and a little broader than thorax (11:9). Vertex strongly reticulate-sculptured, posterior portions just behind eyes rounded; occiput well developed with finely reticulate-sculptured throughout. Frons more broadly and more distinctly reticulate than those of kuboi, this sculpture shows somewhat transverse tendency; frons above antennal toruli smooth and shining, with a few punctures along the inner orbit; subocular space microscopically sculptured near eye. Eyes with extremely short hairs, 1.2 times as long as broad; interocular distance about 0.5 times as long as width of head as seen in front. Posterior ocelli very close to inner orbit; posterior ocellar distance 1.7 times as long as lateral ocellar distance. Antennae lo-segmented; radicle 


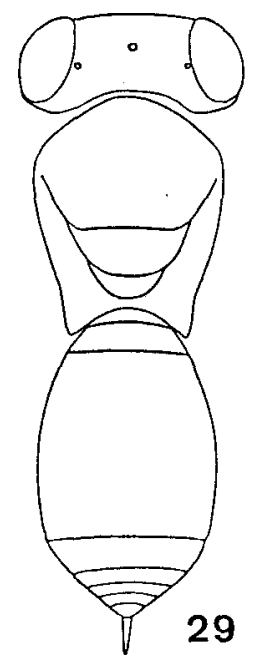

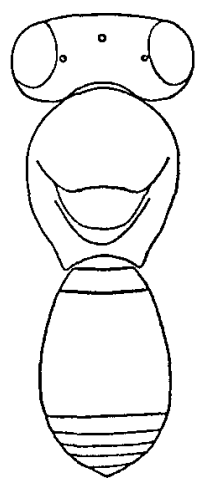

30

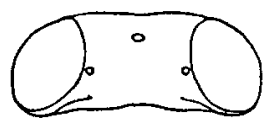

31

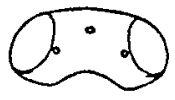

32

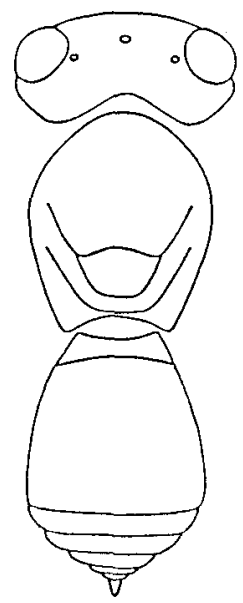

33

Figs. 29-33: Body and head of Telenomus spp., dorsal view. 29: T. dendrolimi (Matsumura), 30: T. sudoensis Ryu, sp. n., 31: T. kyushuensis Ryu, sp. n., 32: T. gifuensis Ashmead, 33: T. acrobates Giard.

rather short, about 1.8 times as long as broad; scape a little shorter than pedicel and four funicle segments combined, about 5.6 times as long as broad; pedicel twice as long as broad, 1.2 times as long as first funicle segment; first about 1.5 times as long as broad, 1.4 times as long as second; second hardly longer than broad, 1.4 times as long as third; third and fourth transverse; club 4-segmented, proximal first segment quadrate, second and third transverse and apical segment conical-ovate.

Thorax a little longer than broad (11:9) ; mesoscutum distinctly convex, reticulate-sculptured as in vertex; scutellum entirely smooth, and shining with some scattered punctures ; postscutellum very short, distinctly sculptured. Fore wings about 2.9 times as long as broad, venation brownish and sharply defined; postmarginalis about 1.9 times as long as stigmalis and submarginalis 1.5 times as long as postmarginalis. Hind wings 6 times as long as broad; fringes nearly $1 / 2$ of the greatest width of hind wing.

Metasoma distinctly longer than broad (11:7), slightly narrower than thorax; first tergum distinctly transverse, longitudinally costate on basal half; second tergum hardly longer than broad, striated at base; following terga strongly transverse with sparse hairs.

Lengh : $0.95 \mathrm{~mm}$.

Male and host: Unknown.

Distribution: Japan (Kyushu).

Type material: Holotype: female (Type No. 2219, Kyushu Univ.), AmamiOshima, Kagoshima Pref., Kyushu, 9. xi. 1962 (A. Azim). Paratype: 1 female, Higashigusuku, Amami-Oshima, Kagoshima Pref., Kyushu, 13. xi. 1962 (A. Azim). 


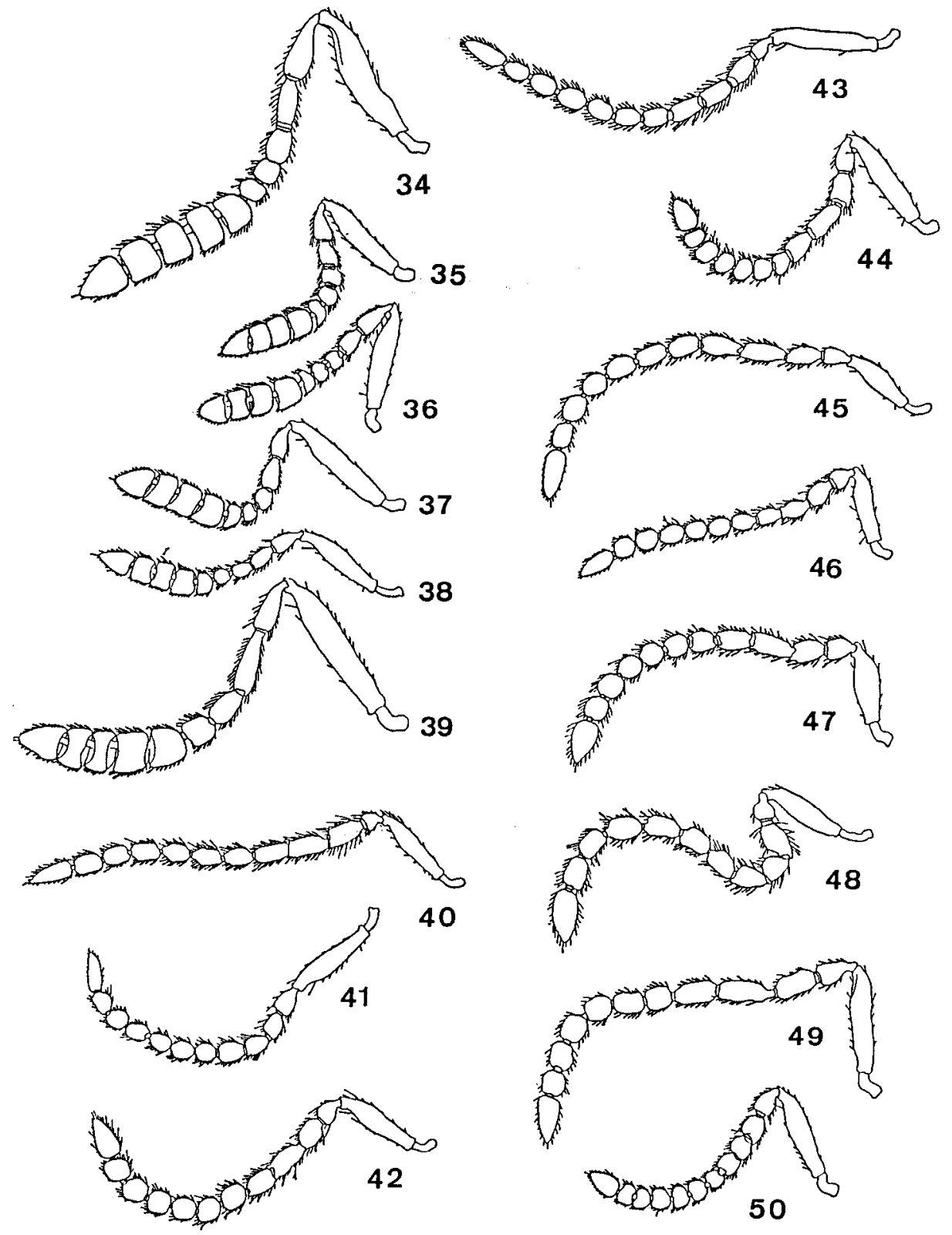

Figs. 34-50: Antennae of Telenomus spp. 35-39: females, 40-50: males.

34: T. dendrolimi (Matsumura), 35: T. kuboi Yasumatsu, 36: T. euproctidis Wilcox, 37: T. kyushuensis Ryu, sp. n., 38: T. monodactylus Liu, 39 : T. sudoensis Ryu, sp. n., 40: T. nakagawai Watanabe, 41: T. cirphivorus Liu, 42: T. acrobates Giard, 43 : T. gifuensis Ashmead, 44 : T. promachivorus (Gahan), 45: T. strelzovi Vassiliev, 46: T. dignus Gahan, 47: T. wullschlegeli Mayr, 48: T. yamagishii Ryu, sp. n., 49: T. dendrolimi (Matsumura), 50: T. euproctidis Wilcox. 


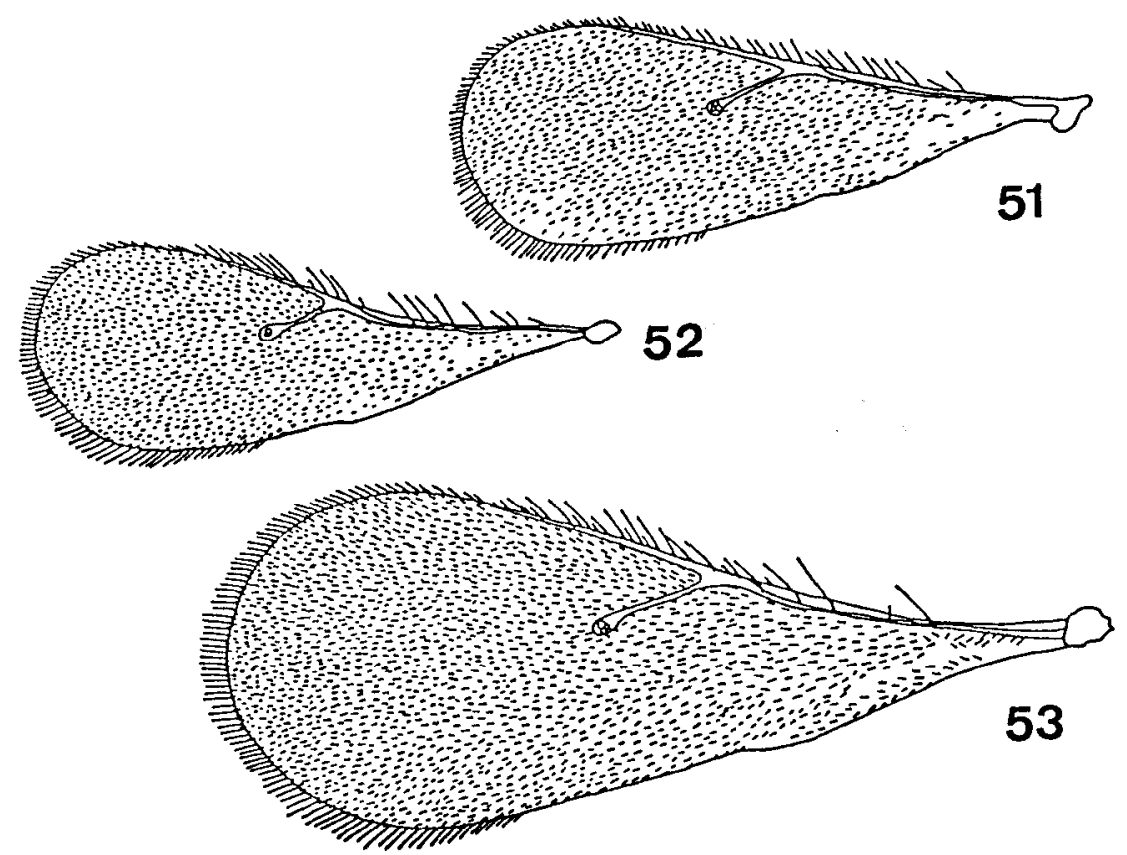

Figs. 51-53: Female fore wings of Telenomus spp. 51: T. dendrolimi (Matsumura), 52: T. kyushuensis Ryu, sp. n., 53: T. sudoensis Ryu, sp. n.

\section{(III) Ungrouped $S$ pecies}

One species (Telenomus atamiensis) was originally described from two specimens collected by A. Koebele at Atami. The lectotype was designated by Masner and Muesebeck in 1968. According to them, the lectotype male is fragmentary, only the abdomen, left wings, and hind legs are remaining. The cotype male is missing. Unfortunately, we were not able to determine this species based on the original description which is too brief to indicate the species characters. Therefore, this species is excluded and placed in the "ungrouped species" and the original description is cited.

\section{Telenomus atamiensis Ashmead}

Telenomus atamiensis Ashmead, 1904, J. N. Y. Ent. Soc., 12: 72. Male. Liophanurus atamiensis: Kieffer, in André, 1912, Spec. Hym. Eur., 11: 61. Phanurus atamiensis: Kieffer, 1926, Das Tierreich, 48: 57. Male.

Telenomus atamiensis: Masner and Musesbeck, 1968, U. S. Nat. Mus. Bull., 270: 62.

Male. - Length, 0.70-0. $75 \mathrm{~mm}$. Black and shining, the head smooth, impunctate, wider than thorax, about $3 \mathrm{l} / \mathrm{Z}$ times as wide as thick, antero-posteriorly, the eyes light-colored, the mesonotum with a few very minute scattered punctures; flagellum dark brown, pubescent, the scape and the pedicel 
except at extreme apex which is yellowish, black; wings hyaline, pubescent, the veins brown, the marginal vein very short, only about one third the length of the stigma1 vein which ends in a small knob; abdomen short oval, hardly longer than the thorax, depressed, smooth and shining, except the first segment which is delicately striated; legs black or brown-black, the trochanters, tips of femora, tips of tibiae and all tarsi yellow.

Type. - No. 7122, U. S. National Museum.

Atami. Two specimens collected by Mr. A. Koebele.

\section{Key to Japanese and Korean Species (Females) of Telenomus}

Antennae 11-segmented

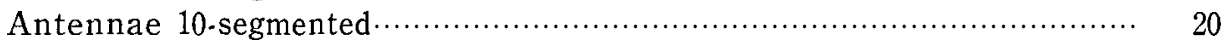

Metasoma considerably elongate with long ovipositor; about apical half of metasoma cylindrical; 1st metasomal tergum strongly convex dorsally; head rather small for length of body; very distinct species, length about

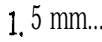
...promachivorus (Gahan)

Metasoma not considerably elongate and not cylindrical …..................... Minute species, length about $0.57 \mathrm{~mm}$; eyes bare ; 2nd tergum piceous or more paler (raddish brown), long, smooth, very shining, with a transverse row of microscopical punctures at base; upper portion of head just behind upper portion of eye very narrow, somewhat angulate behind......

Larger, with eyes hairy; when minute, head rounded............................... 4 Antenna1 club 6-segmented; head, as seen from above, transverse, rounded laterally, with posterior margin slightly emarginate; vertex well convex, rounded posteriorly; upper portion of head with space between eyes narrow and with distinct ocellar triangle; posterior ocelli broadly separated from posterior margin of head as seen from above; thorax rather slender, narrower than head, mesoscutum strongly convex dorsally; met. asoma slightly longer than thorax with large and long 2nd tergum; length 1. 2-l. $4 \mathrm{~mm}$................................................. koreanus Ryu, sp. n. Antennal club 5-segmented or not well formed ….............................. 5 Head, as seen from above, postero-lateral portions angulate, space behind eye nearly obsolete or linear and usually sharply carinate $\cdots \cdots \ldots \ldots \ldots . \cdots 6$ Head, as seen from above, postero-lateral portions rounded, space behind eye not linear, well marked; vertex rounded behind ….........................10 First funicle segment very long, much longer than pedicel which is about or more than twice as long as broad; upper portion of head including vertex well reticulate; as seen from above, posterior margin of head distinctly angulate or nearly carinate behind eye and rather rounded in the middle; metasoma slightly longer than thorax, broadest beyond the middle; 2nd tergum large, long, smooth and very shining except for basal longitudinal wrinkles; 3rd and following terga very short, total length of them shorter than 1st tergum; length about $1.4 \mathrm{~mm}$. 


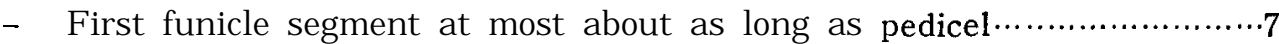

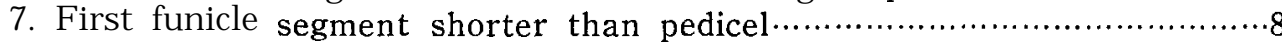

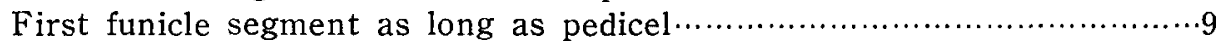

8. Very small species, length $0.6-0.7 \mathrm{~mm}$; scape and legs not clear yellow, slightly darkened with brown; frontal depression weak, not distinctly indicated; hind wing slender, with long marginal hairs which are almost as long as width of hind wing .................................... cirphivorus Liu

- Slightly larger, length about $0.9 \mathrm{~mm}$; scape and legs, including coxae, yellow; frons well convex, smooth and very shining; frontal depression distinctly indicate; hind wing rather broad, with long marginal hairs much shorter than width of hind wing ....................................ucullus Nixon

9. First funicle segment as long as 2nd and 3rd segments together (2nd only slightly longer than broad, 3rd rounded) ; vertex finely but rather distinctly reticulate; frons in front of mid ocellus well convex; interocular distance rather short; head, as seen from side, with eyes large and distance between eye and mandible short; antennae dark brown to black, with scape light yellowish brown or nearly yellow; legs (including coxae) yellow; apical portion of metasoma with dorsal face distinctly slanting; length

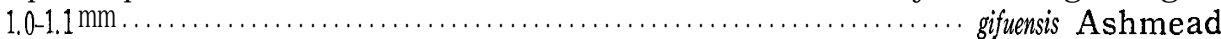
First funicle segment shorter than 2nd and 3rd segments combined (2nd segment longer than broad and 3rd about as long as broad) ; vertex rather narrow, well convex and finely reticulate; frons well convex, in greater part smooth and shining; subocular space microscopically sculptured near eye; head, as seen from side, with eyes rather small and distance between eye and mandible rather long; scape and legs distinctly brownish; dorsal face of metasoma as usual, not very slanting apically; length

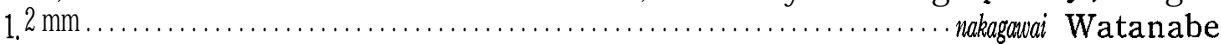

10. Metasoma distinctly longer than head and thorax combined; 1st tergum virtually unsculptured; 2nd tergum about 1.4 times as long as broad; ovipositor very long, about 0.6 times as long as metasoma; vertex broad, roundly convex into occiput; occiput concave and preoccipital carina situated below the top of vertex; antennae dark brown to black; legs

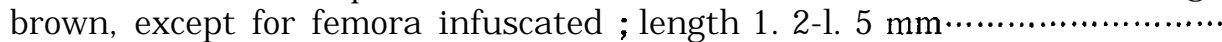

Crawford

- Metasoma shorter than head and thorax combined; when slightly longer, it is concave

11. Thorax dorso-ventrally distinctly compressed ; mesoscutum flat and broad; scutellum also flat; metasoma distinctly concave, about twice as long as broad; head, as seen from above, not thick, transverse; frons hardly convex, rather broadly flat, with scattered punctures; fringes of hind wing about $2 / 3$ of the greatest width of wing; antennae dark brown to black; legs brownish black, except for apex of tibiae and tarsi yellowish brown;

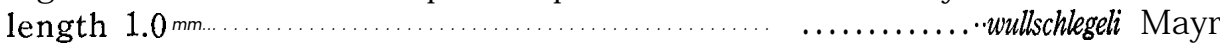

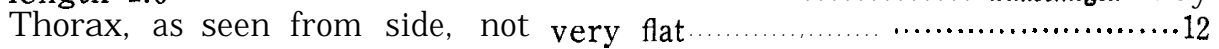

12. Very small, slender species, length about $0.6 \mathrm{~mm}$; head rounded and slightly convex in front as seen from above; posterior portions of eyes 
very well developed; eyes small when seen from above but large as seen from side; face situated on ventral part of head because frons strongly produced anteriorly

"spheeroceps Ryu, sp. n.

- Larger (but small) species; frons not produced anteriorly..................13

13. Antennae with 4 distal segments blackish, swollen, forming a distinct club; the rest of antennae yellow; legs (including coxae) also yellow; head, as seen from above, with portions behind compound eyes well developed and rounded; vertex well convex, space between vertex and posterior margin of head broad; 2nd tergum finely sculptured (primarily longitudinally striate) nearly all over; length about $0.9 \mathrm{~mm}$

.yamagishi Ryu, sp. $\mathrm{n}$.

- Antennae not clearly bicolored; 2nd tergum smooth in the middle..........14

14. Pedicel elongate, about 3 times as long as broad; 1st funicle segment also elongate, a little shorter than pedicel, much longer than $2 \mathrm{nd}$ which is longer than broad and longer than 3rd; length about $1.2 \mathrm{~mm}$, rather robust species; upper portion of head rather broad, more or less flat, finely reticulate, with ocellar triangle not well developed; interocular distance rather long; head, as seen from above, portion behind eye rounded, in outline, not very well developed; thorax not strongly convex dorsally, rather broad; metasoma broad, oval in outline, about 1.5 times as long as broad, with 2nd tergum smooth, very shining, with longitudinal wrinkles only on basal portion

poeta Girault

- Pedicel less than twice as long as broad; 2nd funicle segment rounded, moniliform . .15

15. First funicle segment short, about as long as broad or only indistinctly longer, distinctly shorter than pedicel; 2nd funicle segment also short, about as long as 1st; head as seen from above, interocular distance rather short, but longer than width of eye; scape brownish; legs variegated with brown, not all yellow; length $0.95 \mathrm{~mm} \ldots \ldots \ldots \ldots \ldots \ldots \ldots$ strelzovi Vassiliev

- First funicle segment much longer than broad, about as long as pedicel...

16. Head, as seen in front, interocular distance very narrow, about 0.4 times as long as width of head; 2nd funicle segment also elongate, about 2.3 times as long as broad; scape yellow and pedicel yellowish; legs clearly yellow; length $1.0 \mathrm{~mm}$.......................................... Telenomus $\mathrm{sp}$.

- Head, as seen in front, interocular distance rather broad, longer than

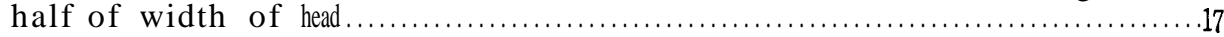

17. Club of antennae distinctly 5-segmented; antennae nearly entirely blackish ; compact and rather broad species; metasoma rather short, broadest much beyond the middle, thence abruptly narrowed toward the apex; 2nd tergum with several short longitudinal carinae in the middle basally; head broader than thorax, posterior portion behind eye more or less well developed; posterior portion of vertex slanting toward behind, with a nearly complete preoccipital carina situated below the top of vertex ; length 0.9 $1.0 \mathrm{~mm}$ 


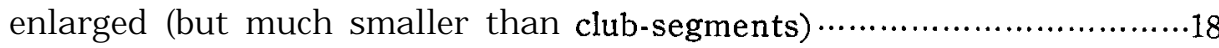

18. Very small and slender species; metasoma long and slender, distinctly concave in dried specimens; antennae slender, rather long, four apical segments slightly enlarged to form a club, but the proximal segment not distinctly large; four basal funicle segment very short, round, each segment shorter than pedicel which is also short (a little longer than broad) ; head rouned, rather small, scarcely broader than thorax; length $0.8 \mathrm{~mm}$...

- Metasoma either slender or rather broad, but not concave; head transverse, broader than thorax (although very slightly so) $\ldots \ldots \ldots \ldots \ldots \ldots \ldots \ldots \ldots 19$

19. Club of antennae thick, clearly 4-segmented; metasoma small, short and slender, 1.3 times as long as broad; thorax, as seen from side, distinctly convex as usual; fringes of hind wing about $2 / 3$ of the greatest width of wing; antennae and legs dark brown to black, except for basal segments of tarsi yellowish brown; length $0.7-0.8 \mathrm{~mm} \ldots \ldots \ldots \ldots \ldots \ldots \ldots \ldots \ldots$ acrobates Giard

- Club of antennae rather slender; head, as seen from above, thick and rather rounded, with interocular distance rather narrow; vertex well convex, distinctly reticulate ; posterior portion of mesoscutum rather flat ; scutellum also slightly convex; thus, thorax not distinctly convex as seen from side; metasoma not small, more or less long and broad, about 2.1 times as long as broad; legs clearly yellow, except for apices of tarsi slightly darkened ; length $0.7-0.8 \mathrm{~mm} \ldots \ldots \ldots \ldots \ldots \ldots \ldots \ldots \ldots \ldots$ digmus (Gahan)

20. Club of antennae distinctly 5 -segmented with the proximal segment as large as next segment; pedicel elongate, about twice as long as broad; 1st funicle segment also elongate, slightly longer than pedicel; 2nd and 3rd small, distinctly smaller than the proximal segment of club; head, as seen from above, transverse, with broad interocular distance, which is a little longer than length of eye in frontal view (about $9: 8$ ); as seen from side, eye rather short and the space between eye and mandible long; upper portion of genal area distinctly carinate just along eye margin; 2nd metasomal tergum longer than broad, glabrous as usual; length $1.3 \mathrm{~mm}$.

..sudennis Ryu, sp. $\mathrm{n}$.

- Club of antennae 4-segmented, but sometimes appearing 5-segmented because the 4th funicle segment slightly enlarged, but distinctly smaller than the 5th funicle segment (=the proximal segment of club) $\cdots \ldots \ldots \ldots . . .21$

21. Minute species, length about $0.65 \mathrm{~mm}$; metasoma broadly concave in dried specimens ; head slightly broader than thorax as seen from above, rather thick, well convex anteriorly in outline; vertex and frons well convex; interocular distance broad; seen from side, eyes large and the space between eye and mandible short; thorax more or less short, broadest at the level of tegulae, distinctly narrowed posteriorly; upper portion of genal area and just behind eye linear, not carinate but sharp....

monodactylus Liu

- Large, at least $0.75 \mathrm{~mm}$ in length; metasoma not concave, as usual $\cdots \ldots 22$

22. Head, as seen from above, transverse and distinctly broader than thorax; vertex transversely well convex, distinctly slanting, so that the habitus of upper portion of head much different from that of the following species; 
vertex and upper frons finely reticulate, but frons just in front of mid ocellus smooth and shining; 1st metasomal tergum transversely well convex, nearly smooth and shining except for the extreme base which is longitudinally carinate ; metasoma narrower than thorax; 2nd tergum long-

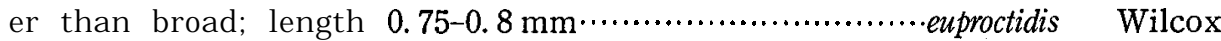

- Head, as seen from above, more or less thick, rather rounded in outline (especially posterior portion of eye rounded, this portion rather angulate in euproctidis and in kuboi); frontal region well convex; finely reticulate

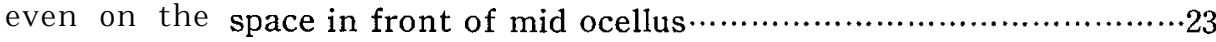

23. Frons with the space just in front of mid ocellus shining, very finely reticulate; head, as seen from above, posterior portion of eye rounded, but with a carina along upper-hind margin of eye; metasoma about as broad as or a little broader than thorax; 2nd metasomal tergum about as long as broad; fringes of hind wing about $2 / 3$ of the greatest width of wing;

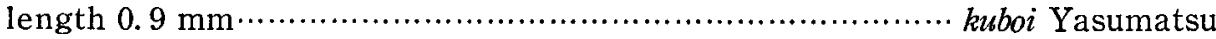

- Vertex similar to the preceding species, but frons more broadly and more distinctly reticulate; mesoscutum more roundly convex; the distance between eye and mandible longer in lateral view; metasoma slightly narrower than thorax, and 1st tergum less extensively longitudinally carinate ;

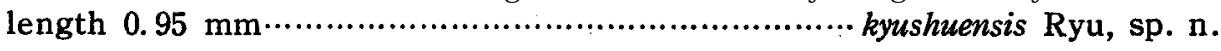

\section{REFERENCES}

Ashmead, W. H. 1893 A monograph of the North American Proctoturupidae. Bull.U. S. nat. Mus., 45: 1-472

Ashmead, W. H. 1903 Classification of the pointed-tailed wasps, or the superfamily Proctotrypoidea. J. New. York ent. Soc., 11: 86-99

Ashmead, W. H. 1904 Descriptions of new Hymenoptera from Japan. Ibid., 12 (2) : 65-83

Baltazar, C. R. 1966 A catalogue of Philippine Hymenoptera (with a bibliography, 17851963). Pacific Incect Monog., 8: 1-488

Bruce, C. T. 1908 Hymenoptera Fam. Scelionidae. Genera Insectorum, fasc. 80: 1-59, 2 pls.

Crawford, J. C. 1911 Descriptions of new Hymenoptera, 2. Proc.U. S. nat. Mus., 40: 439449

Dalla Torre, C. G. 1899 Catal. Hymenopterorum, 5. Chalcididae et Proctotrupidae. 598 pp.

Eady, R. D. 1968 Some illustrations of microsculpture in the Hymenoptera. Proc. R. ent. Soc. Lond. (A), $43:$ 66-72

Gahan, A. B. 1924 Some new parasitic Hymenoptera with notes on several described forms. Proc.U. S. nat. Mus., 65: 1-23

Gahan, A. B. 1925 A second lot of parasitic Hymenoptera from the Philippines. Philip. J. Sci., 27 (1) : 83-109

Girault, A. A. 1920 New Serphidoid Cynipoid and Chalcidoid Hymenoptera. Proc.U. S. nat. Mus., 58; 177-216

Gorad, A. 1895 Sur quelques espéces nouvelles d'Hymènoptéres parasites. Bull. Soc.ent. France, 1895 : 124-130

Hidaka, T. 1958 Biological investigation on Telenomus gifuensis Ashmead (Hym. :Scelionidae), an egg-parasite of Scotinopharalurida Burmeister (Hem.: Pentatomidae) in Japan.

Acta Hym., 1: 75-93 
Hirashima, Y. and K. Yamagishi 1981 Redescriptions of some Japanese Scelionidae preserved in the United States National Museum (Hymenoptera, Proctotrupoidea). J. Fac. Agr., Kyushu Univ, 25 (4) : 153-159

Hirose, Y., M. Shiga and F. Nakasuji 1968 Interspecific relations among three hymenopterous egg parasites of the pine moth, Dendrolimus spectabilis Butler (Lepidoptera : Lasiocampidae) in the Japanese black pine forest. II. Spatial interspersion of the two egg parasites, Trichogramma dendrolimi and Telenomus dendrolimi in the pine crown. J. Fac.Agr., Kyushu Univ., 14 (3) : 459-472

Ishii, T. 1938 Chalcidoid- and Proctotrypoid-wasp reared from Dendrolimus spectabilis Butler and D. albolineatus Matsumura and their insect parasites, with descriptions of three new species. Kontŷu, Tokyo, 12: 97-105

Ishii, T. 1939 New Chalcidoid and Proctotrupoidea wasps reared from forest insects by Dr. H. Kono. Kontyû, Tokyo, 13: 187-191

Javahery, M. 1968 The egg parasite complex of British Pentatomoidea (Hemiptera): taxonomy of Telenominae (Hymenoptera: Scelionidae). Trans. R. ent. Soc. Lond., 120: 417-436, 2 pls.

Kieffer, J. J. 1910 Hymenoptera Fam. Scelionidae. Genera Insectorum, fasc. 80B: 61-112, $1 \mathrm{pl}$.

Kieffer, J. J. 1926 Scelionidae. Das Tiereich, 48: 1-131

Kozlov, M. A. 1967 Palearctic species of egg parasites of the genus Telenomus Haliday (Hymenoptera : Scelionidae : Telenominae). Ent. Obozr., 46: 361-378 (In Russian). Translated in: Ent. Rev., Washington, 46: 215-224

Kozlov, M. A. 1968 Telenominae (Hymenoptera, Scelionidae) of the Caucasus-egg parasites of hemipterous grain pests. Trudy uses. ent. O bschch., 52: 188-223 (In Russian)

Krombein, K. V., P. D. Hurd, Jr., D. R. Smith and B. D. Burks 1979 Catalog of Hymenoptera in America North of Mexico, 1: 1-1198 (Scelionidae by C. F. W. Muesebeck, pp. 11501171)

Liu, C. L. 1959 Contribution to generic definition of Telenomus by two new Chinese species (Hym., Scelionidae). ActaSoc. ent. Čsl., 56: 155-160

Mansner, L. 1964 A comparison of some Nearctic and Palaearctic genera of Proctotrupoidea (Hymenoptera) with revisional notes. Acta Soc. ent. $\check{C} s l ., 61$ (2) : 145-146

Masner, L. 1976 Revisionary notes and keys to world genera of Scelionidae (Hym., Proct.). Mem. Ent. Soc.Canad., 97: 1-87

Masner, L. 1979 Pleural morphology in Scelionid wasps (Hym.: Scel.)-an aid to higher classification. Can. Ent., 111: 1079-1087

Masner, L. 1980 Key to genera of Scelionidae of the Holarctic Region, with descriptions of new genera and species (Hym.: Proctotrupoidea). Mem. Ent. Soc.Canad., 1la: 54 PP.

Matsumura, S. 1925 On the three species of Dendrolimus (Lepidoptera), which attack spruce- and fir-trees in Japan, with their parasites and predaceous insects. Ann. M us. Zool. Acad. Sci. l'URSS: 27-50

Mayr, G. 1879 Ueber die Schlupfwespengattung Telenomus. Verh. zool.-bot. Ges. Wien, 29: $697-714$

Nakagawa, H. 1900 Illustration of some Japanese Hymenoptera parasitic on insect eggs. I. Spec. Rep. Agr. Exp. Stat., 6: I-26, 7 pls. (In Japanese)

Nixon, G. E. J. 1937 New Asiatic Telenominae (Hym.: Proctotrupoidea). Ann. Mag. nat. Hist., (10) 20: 113-127, 444-475

Nixon, G. E. J. 1938 Five new Asiatic Telenominae (Hym. : Proctotrupoidea). Ann. Mag. nat. Hist., (11) 1: 584-593

Ryu, J. and Y. Hirashima 1984 Taxonomic studies on the genus Trissolcus Ashmead of Japan and Korea (Hymenoptera, Scelionidae). J. Fac. Agr., Kyushu Univ., 29 (1) : 35-58 
Tachikawa, T. 1977 Hymenopterous parasites of the eggs of Plautiastali Scott (Hemiptera: Pentatomidae) in Japan. Trans. Shikoku Ent. Soc., 13: 132

Watanabe, C. 1951 On five Scelionid egg-parasites of some Pentatomid and Coreid bugs from Shikoku, Japan (Hymenoptera: Proctotrupoidea). Trans. Shikoku Ent. Soc., 2 (2): $16-26$

Watanabe, C. 1954 Discovery of four new species of Telenominae, egg-parasites of Pentatomid and Plataspid bugs, in Shikoku, Japan (Hymenoptera : Proctotrupoidea). Ibid., $4(2): 17-22$

Wilcox, A. M. 1920 Notes and descriptions of species of Telenomus having ten-jointed antennae (Hymenoptera : Scelionidae). Psyche, 27: 78-81

Yasumatsu, K. 1950 On the identity of four Scelionid egg-parasites of some Japanese and Formosan Pyraloid moths (Hymenoptera). Mushi, Fukuoka, 21: 55-60

Yasumatsu, K. 1962 A new species of Telenomus from the Ryukyus (Hym., Scelionidae). Kontyû, Tokyo, 30: 260 